\title{
Data report: grain size distribution of unconsolidated sands offshore Shimokita Peninsula, Japan (IODP Site C0020) ${ }^{1}$
}

\author{
Stephen C. Phillips ${ }^{2,3}$ and Joel E. Johnson ${ }^{3}$
}

\section{Chapter contents}

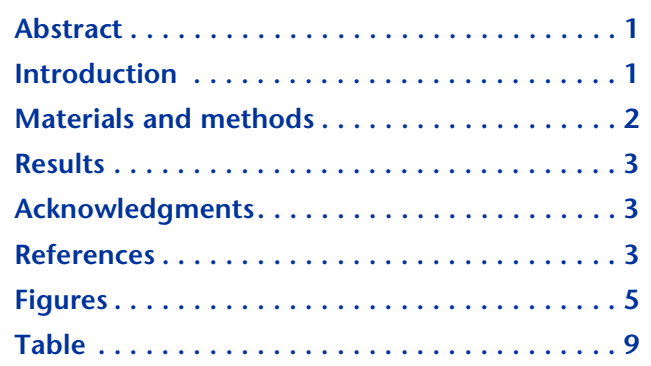

1Phillips, S.C., and Johnson, J.E., 2017. Data report: grain size distribution of unconsolidated sands offshore Shimokita Peninsula, Japan (IODP Site C0020). In Inagaki, F., Hinrichs, K.-U., Kubo, Y., and the Expedition 337 Scientists, Proceedings of the Integrated Ocean Drilling Program, 337: Tokyo (Integrated Ocean Drilling Program Management International, Inc.).

doi:10.2204/iodp.proc.337.203.2017

${ }^{2}$ Department of Earth Sciences, University of New Hampshire, Durham NH 03824, USA.

Correspondence author:

phillips.stephen.c@gmail.com

${ }^{3}$ Institute for Geophysics, Jackson School of Geosciences, University of Texas at Austin, Austin TX 78712, USA.

\begin{abstract}
We report particle size analyses measured from 28 unconsolidated sand samples recovered during Integrated Ocean Drilling Program Expedition 337 from Hole C0020A. These samples span from 1277 to 2002 meters below seafloor (mbsf) across two lithostratigraphic units that record a transition from a nearshore estuarine/ intertidal to an offshore hemipelagic paleoenvironment. Most recovered lithologies, including coarse-grained lithologies, are semiconsolidated to consolidated; however, some intervals of sand are unconsolidated and suitable for particle size analysis. Bulk sand samples were measured using a laser diffraction particle size analyzer. All samples fall within the range of sand to silty sand, with silty sand more abundant deeper than 1925 mbsf. Samples contain $49 \%-97 \%$ sand, 3\%-42\% silt, and $0 \%-13 \%$ clay. Median grain diameter ranges from 55 to $405 \mu \mathrm{m}$. Clay and silt content in these sands reach a minimum at $\sim 1500$ mbsf and then increase below 1925 mbsf in a coal-bearing unit containing shale, siltstone, sandstone, and unconsolidated sand.
\end{abstract}

\section{Introduction}

Integrated Ocean Drilling Program Expedition 337 explored the microbiology and hydrocarbon system associated with subseafloor coal beds in the Hidaka Trough offshore the Shimokita Peninsula, Japan (see the "Expedition 337 summary" chapter [Expedition 337 Scientists, 2013a]) (Inagaki et al., 2015, 2016). Hole C0020A $\left(41^{\circ} 10.5983^{\prime} \mathrm{N}, 142^{\circ} 12.0328^{\prime} \mathrm{E} ; 1180 \mathrm{~m}\right.$ water depth) was drilled to 2466 meters below seafloor (mbsf) as an extension of Japan Agency for Marine-Earth Science and Technology (JAMSTEC) Site C9001, which was originally drilled to 647 mbsf (Aoike, 2007). Spot coring began at $1276.5 \mathrm{mbsf}$ at an interval of approximately one core every $100 \mathrm{~m}$, and near-continuous coring occurred between 1919.0 and 2002.4 mbsf across the coal-bearing target. Cuttings were collected over the entire hole at $10 \mathrm{~m}$ intervals but were not used in this study.

The recovered sediment sequence revealed a transition from offshore marine to nearshore/terrestrial environments that was described in four lithostratigraphic units (Figure F1) (see the "Site C0020" chapter [Expedition 337 Scientists, 2013b]) that span the late Oligocene to early Pleistocene (Phillips et al., 2016). Unit I (647-1256.5 mbsf; no core recovery) is composed of a hemi- 
pelagic, diatom-bearing silty clay, representing a continental slope environment. Unit II (1256.5$1826.5 \mathrm{mbsf}$; 7\% core recovery) is composed of primarily silty shale with common intervals of siltstone and sandstone/unconsolidated sands. Unit II contains an increasing frequency with depth of coarsegrained sediments, terrestrial plant debris, bioturbation, and cross-lamination, along with a decrease in diatom abundance, suggesting a continental shelf to intertidal environment. Cruziana ichnofacies were observed in Unit II. Well logging results indicate a massive $60-70 \mathrm{~m}$ thick sandstone in Unit II and three coal layers (0.3-0.6 m thick) that were not sampled by coring. Unit III (1826.5-2046.5 mbsf; 35\% recovery) contains multiple coal beds with intervals of sandstone/sand, siltstone, and shale. Flaser bedding, cross bedding, and authigenic carbonate nodules are present in Unit III. Sharp increases in magnetic susceptibility driven by authigenic magnetite precipitation are present in Unit III (Phillips et al., 2017). Unit III represents a nearshore environment with coals derived from brackish wetlands at the top of Unit III and freshwater wetlands at the base of Unit III (Gross et al., 2015). Unit IV (2046.5-2466 mbsf; $8 \%$ core recovery) consists of shale, sandstone, and siltstone, representing a tidal flat to fluvial environment, and is largely devoid of coal except for a 30 $\mathrm{cm}$ coal bed at the very bottom of the hole. Unit IV also contains numerous authigenic carbonate nodules.

Particle size distribution in marine and terrestrial sediments can provide insight into paleoenvironmental conditions driven by climatic and tectonic changes (e.g., Orton and Reading, 1993; Goman and Wells, 2000; Ding et al., 2002; Warner and Domack, 2002; Asikainen et al., 2007). In addition, grain size can influence microbial biomass and microbial activity and diversity in a range of marine and terrestrial environments (e.g., Dale, 1974; Bender and Conrad, 1994; Sessitsch et al., 2001; Noffke et al., 2002). Thus, grain size analysis of sediments at Site C0020 has the potential to provide insight on paleoenvironmental and microbial processes offshore Shimokita Peninsula since the late Oligocene.

A complete downcore sampling strategy for grain size analysis from each unit and throughout the entire hole was not possible because most cored samples from Site C0020 were consolidated or semiconsolidated, including all samples of siltstone and finer grained lithologies. These consolidated or semiconsolidated sediments cannot be accurately analyzed because intense disaggregation imparts error into the grain size distribution (Gealy, 1971; Thayer et al., 1974). However, multiple intervals of uncon- solidated sands were recovered across Units II and III. No cores were collected in Unit I (only cuttings), and all sediments in Unit IV were lithified. Accordingly, we report the results of particle size analysis of 28 unconsolidated sand samples from Units II and III.

\section{Materials and methods}

All measured samples were unconsolidated sands based on visual core description and required no crushing to loosen individual grains. We measured bulk, untreated samples containing all lithogenic, biogenic, and authigenic components. These 28 unconsolidated sand samples were selected out of a set of 144 samples originally collected for a separate rock magnetic and geochemical study (Phillips et al., 2017) that covers the full range of major lithologies. The samples measured here are representative of the unconsolidated sands recovered from Hole C0020A. Collection of these samples was conducted to avoid contamination of drilling mud (Figure F2).

Each sample was treated with $20 \mathrm{~mL}$ of a $5.0 \mathrm{~g} / \mathrm{L}$ sodium hexametaphosphate dispersing agent. Each sample was then agitated using a vortex mixer, left for a minimum of $24 \mathrm{~h}$, and then agitated again immediately before analysis.

All samples were measured using Malvern Mastersizer 2000 laser diffractometer particle size analyzer with a Hydro 2000 wet dispersion unit. Our method is based on the approach of Sperazza et al. (2004). Grain size measurements were made using a particle refractive index of 1.55 , a dispersant refractive index of 1.33, and a particle absorption index of 0.01 .

All samples were passed through a $2 \mathrm{~mm}$ (\#10 mesh) sieve before entering the dispersion unit, and no material $>2 \mathrm{~mm}$ was observed on the sieve in any sample. Each sample was completely dispersed in the dispersion unit to avoid subsampling errors, which generally have a higher impact on sample uncertainty than obscuration rate (Sperazza et al., 2004). Samples in sodium hexametaphosphate were added to the dispersion unit and diluted to obtain an obscuration between $8 \%$ and $22 \%$ (average $=14 \%$ ). The pump speed was run at $2000 \mathrm{rpm}$, the stirrer was run at $770 \mathrm{rpm}$, and the sample was sonicated for $10 \mathrm{~s}$ prior to the sample analysis.

Grain size distributions are reported as frequencies in 89 diameter bins from 0.01 to $2187 \mu \mathrm{m}$. Median, tenth percentile $(\mathrm{d}(0.1))$, and ninetieth percentile $(\mathrm{d}(0.9))$ were calculated from this distribution using the accompanying Mastersizer software. Mean grain size was calculated as both a surface area moment mean (Sauter mean diameter or $\mathrm{D}[3,2]$ ) and a vol- 
ume moment mean (De Brouckere mean diameter or $\mathrm{D}[4,3])$. We calculate sand (>63 $\mu \mathrm{m})$, silt $(4-63 \mu \mathrm{m})$, and clay $(<4 \mu \mathrm{m})$ from each sample's grain size distribution based on the classification of Wentworth (1922).

The Mastersizer 2000 was calibrated with a Malvern glass sphere standard with mean diameter $(\mathrm{d}(0.5))$ of $61 \mu \mathrm{m}$, tenth percentile $(\mathrm{d}(0.1))$ of $37 \mu \mathrm{m}$, and ninetieth percentile $(\mathrm{d}(0.9))$ of $90 \mu \mathrm{m}$. A local, well-sorted sand from Wallis Sands Beach in Rye, New Hampshire (US), was run four times throughout the run of samples as a check standard for consistency. This check standard repeated to within $<1 \mu \mathrm{m}$ for all mean and percentile statistics: $D[3,2]=242 \mu \mathrm{m}$, $\mathrm{D}[4,3]=262, \mathrm{~d}(0.1)=175 \mu \mathrm{m}, \mathrm{d}(0.5)=251 \mu \mathrm{m}$, and $\mathrm{d}(0.9)=362 \mu \mathrm{m}$.

One sample (337-C0020A-5R-3, 36-39 cm) was run in duplicate as a measure of repeatability across the range of obscuration ( $9 \%$ and $17 \%)$.

\section{Results}

All samples are primarily sand sized with the primary peak of the distribution in the fine-to-medium sand range (Figures F3, F4; see SAMPLES in Supplementary material). Each sample has a low and variable amount of fine-grained material represented by a long tail on the left of the distribution. Each sample from Units II and III falls within the range of $49 \%-$ $97 \%$ sand, $3 \%-42 \%$ silt, and $0 \%-13 \%$ clay (Table T1). Based on the classification system of Shepard (1954), all samples fall within the range of sand or silty sand, with silty sand samples more common in Unit III (Figure F5). Median grain diameter d(0.5) ranges from 55 to $405 \mu \mathrm{m}$. Surface area-weighted mean diameter $\mathrm{D}[3,2]$ ranges from 9 to $178 \mu \mathrm{m}$, and volume-weighted mean diameter $\mathrm{D}[4,3]$ ranges from 77 to $400 \mu \mathrm{m}$.

The overall coarsest unconsolidated material recovered from Hole C0020A is found in the middle of Unit II between 1377 and 1630 mbsf, indicated by the highest percent sand, lowest percent silt and clay, and highest values of $\mathrm{d}(0.1)$ (Figure F6). Within Unit III, the percent sand decreases downhole, and silt and clay contents increase relative to Unit II. Median grain size decreases in Unit III corresponding to the increase in clay content. Sand samples from the upper $30 \mathrm{~m}$ of Unit III (Figure F7) in general have lower clay content, higher silt content, and higher $\mathrm{d}(0.1)$ compared to the lower intervals of Unit III.

Sample 337-C0020A-5R-3, 36-39 cm, run in duplicate, shows the sand-silt-clay percentages are repeat- able to within $1 \%$ and $\mathrm{d}(0.5)$ matches within $5 \mu \mathrm{m}$. $\mathrm{d}(0.1)$ and $\mathrm{d}(0.9)$ repeat within 6 and $20 \mu \mathrm{m}$, respectively. $\mathrm{D}[4,3]$ and $\mathrm{D}[3,2]$ repeat within 6 and $13 \mu \mathrm{m}$, respectively.

Our grain size measurement from the uppermost sample in Unit III (1925.21 mbsf) is consistent with the grain size distribution of one sample from 1925.38 mbsf measured via sieve analysis by Ijiri et al. (2017). Overall, these results show systematic changes downhole that may provide insight to paleoenvironmental conditions and the role of the host material for microbial activity.

\section{Acknowledgments}

We thank the Captain and crew of the D/V Chikyu and the IODP Expedition 337 scientists and technicians for core collection and initial onboard analysis. We are grateful for the support of IODP and the Ministry of Education, Culture, Sports, Science and Technology of Japan. Samples and/or data were provided by IODP. We appreciate the review and comments from John Jaeger.

\section{References}

Aoike, K. (Ed.), 2007. CDEX Laboratory Operation Report: CK06-06 D/V Chikyu shakedown cruise offshore Shimokita: Yokohama (CDEX-JAMSTEC).

Asikainen, C.A., Francus, P., and Brigham-Grette, J., 2007. Sedimentology, clay mineralogy and grain-size as indicators of $65 \mathrm{ka}$ of climate change from El'gygytgyn Crater Lake, Northeastern Siberia. Journal of Paleolimnology, 37(1):105-122.

https://doi.org/10.1007/s10933-006-9026-5

Bender, M., and Conrad, R., 1994. Methane oxidation activity in various soils and freshwater sediments: occurrence, characteristics, vertical profiles, and distribution on grain size fractions. Journal of Geophysical Research: Atmospheres, 99(D8):16531-16540. https://doi.org/10.1029/94JD00266

Dale, N.G., 1974. Bacteria in intertidal sediments: factors related to their distribution. Limnology and Oceanography, 19(3):509-518.

https://doi.org/10.4319/10.1974.19.3.0509

Ding, Z.L., Derbyshire, E., Yang, S.L., Yu, Z.W., Xiong, S.F., and Liu, T.S., 2002. Stacked 2.6-Ma grain size record from the Chinese loess based on five sections and correlation with the deep-sea $\delta^{18} \mathrm{O}$ record. Paleoceanography, 17(3):1033. https://doi.org/10.1029/2001PA000725

Expedition 337 Scientists, 2013a. Expedition 337 summary. In Inagaki, F., Hinrichs, K.-U., Kubo, Y., and the Expedition 337 Scientists, Proceedings of the Integrated Ocean Drilling Program, 337: Tokyo (Integrated Ocean 
Drilling Program Management International, Inc.). http://dx.doi.org/10.2204/iodp.proc.337.101.2013

Expedition 337 Scientists, 2013b. Expedition 337 Site C0020. In Inagaki, F., Hinrichs, K.-U., Kubo, Y., and the Expedition 337 Scientists, Proceedings of the Integrated Ocean Drilling Program, 337: Tokyo (Integrated Ocean Drilling Program Management International, Inc.). http://doi.org/10.2204/iodp.proc.337.103.2013

Gealy, E.L., 1971. Grain size of sediments from the western equatorial Pacific: Leg 7, Glomar Challenger. In Winterer, E.L. et al., Initial Reports of the Deep Sea Drilling Project, 7: Washington DC (U.S. Govt. Printing Office), 10271036. https://doi.org/10.2973/dsdp.proc.7.122.1971

Goman, M., and Wells, L., 2000. Trends in river flow affecting the northeastern reach of the San Francisco Bay Estuary over the past 7000 years. Quaternary Research, 54(2):206-217.

https://doi.org/10.1006/qres.2000.2165

Gross, D., Bechtel, A., and Harrington, G.J., 2015. Variability in coal facies as reflected by organic petrological and geochemical data in Cenozoic coal beds offshore Shimokita (Japan)—IODP Exp. 337. International Journal of Coal Geology, 152(B):3-79.

http://doi.org/10.1016/j.coal.2015.10.007

Ijiri, A., Ikegawa, Y., and Inagaki, F., 2017. Data report: permeability of $\sim 1.9 \mathrm{~km}$-deep coal-bearing formation samples off the Shimokita Peninsula, Japan. In Inagaki, F., Hinrichs, K.-U., Kubo, Y., and the Expedition 337 Scientists, Proceedings of the Integrated Ocean Drilling Program, 337: Tokyo (Integrated Ocean Drilling Program Management International, Inc.).

https://doi.org/10.2204/iodp.proc.337.202.2017

Inagaki, F., Hinrichs, K.-U., Kubo, Y., Bowles, M.W., Heuer, V.B., Long, W.-L., Hoshino, T., Ijiri, A., Imachi, H., Ito, M., Kaneko, M., Lever, M.A., Lin, Y.-S., Methé, B.A., Morita, S., Morono, Y., Tanikawa, W., Bihan, M., Bowden, S.A., Elvert, M., Glombitza, C., Gross, D., Harrington, G.J., Hori, T., Li, K., Limmer, D., Liu, C.-H., Murayama, M., Ohkouchi, N., Ono, S., Park, Y.-S., Phillips, S.C., Prieto-Mollar, X., Purkey, M., Riedinger, N., Sanada, Y., Sauvage, J., Snyder, G., Susilawati, R., Takano, Y., Tasumi, E., Terada, T., Tomaru, H., Trembath-Reichert, E., Wang, D.T., and Yamada, Y., 2015. Exploring deep microbial life in coal-bearing sediment down to $\sim 2.5 \mathrm{~km}$ below the ocean floor. Science, 349(6246):420-424.

http://doi.org/10.1126/science.aaa6882

Inagaki, F., Hinrichs, K.-U., Kubo, Y., and the Expedition 337 Scientists, 2016. IODP Expedition 337: Deep Coalbed Biosphere off Shimokita-microbial processes and hydrocarbon system associated with deeply buried coalbed in the ocean. Scientific Drilling, 21:17-28. http://dx.doi.org/10.5194/sd-21-17-2016

Noffke, N., Knoll, A.H., and Grotzinger, J.P., 2002. Sedimentary controls on the formation and preservation of microbial mats in siliciclastic deposits: a case study from the upper Neoproterozoic Nama Group, Namibia. PALAIOS, 17(6):533-544. https://doi.org/10.1669/ 0883-1351(2002)017<0533:SCOTFA >2.0.CO;2

Orton, G.J., and Reading, H.G., 1993. Variability of deltaic processes in terms of sediment supply, with particular emphasis on grain size. Sedimentology, 40(3):475-512. https://doi.org/10.1111/j.1365-3091.1993.tb01347.x

Phillips, M.P., Harwood, D.M., and Harrington, G.J., 2016. Neogene and early Pleistocene diatom biostratigraphy and age synthesis of Site C9001/C0020, northwest Pacific. Marine Micropaleontology, 128:39-49. https://doi.org/10.1016/j.marmicro.2016.08.002

Phillips, S.C., Johnson, J.E., Clyde, W.C., Setera, J.B., Maxbauer, D.P., Severmann, S., and Riedinger, N., 2017. Rock magnetic and geochemical evidence for authigenic magnetite formation via iron reduction in coalbearing sediments offshore Shimokita Peninsula, Japan (IODP Site C0020). Geochemistry, Geophysics, Geosystems, 18(6):2076-2098.

https://doi.org/10.1002/2017GC006943

Sessitsch, A., Weilharter, A., Gerzabek, M.H., Kirchmann, H., and Kandeler, E., 2001. Microbial population structures in soil particle size fractions of a long-term fertilizer field experiment. Applied and Environmental Microbiology, 67(9):4215-4224. https://doi.org/ 10.1128/AEM.67.9.4215-4224.2001

Shepard, F.P., 1954. Nomenclature based on sand-silt-clay ratios. Journal of Sedimentary Research, 24(3):151-158. http://dx.doi.org/10.1306/D4269774-2B26-11D78648000102C1865D

Sperazza, M., Moore, J.N., and Hendrix, M.S., 2004. Highresolution particle size analysis of naturally occurring very fine-grained sediment through laser diffractometry. Journal of Sedimentary Research, 74(5):736-743. http://dx.doi.org/10.1306/031104740736

Thayer, P.A., Hostettler, J., and Smith, S., 1974. Grain-size distribution of sediments from the eastern Indian Ocean: Deep Sea Drilling Project, Leg 27. In Veevers, J.J., Heirtzler, J.R., et al., Initial Reports of the Deep Sea Drilling Project, 27: Washington, DC (U.S. Govt. Printing Office), 507-522.

http://dx.doi.org/10.2973/dsdp.proc.27.123.1974

Warner, N.R., and Domack, E.W., 2002. Millennial- to decadal-scale paleoenvironmental change during the Holocene in the Palmer Deep, Antarctica as recorded by particle size analysis. Paleoceanography, 17(3):8004. http://dx.doi.org/10.1029/2000PA000602

Wentworth, C.K., 1922. A scale of grade and class terms for clastic sediments. Journal of Geology, 30(5):377-392. http://dx.doi.org/10.1086/622910

Initial receipt: 9 December 2016

Acceptance: 3 October 2017

Publication: 11 December 2017

MS 337-203 
Figure F1. Lithostratigraphic summary with coal bed depths, wood/lignite content, diatom content, depositional environment, lithostratigraphic unit, and biostratigraphic age. Modified from Expedition 337 Scientists (2013b) with updated biostratigraphic ages from Phillips et al. (2016).

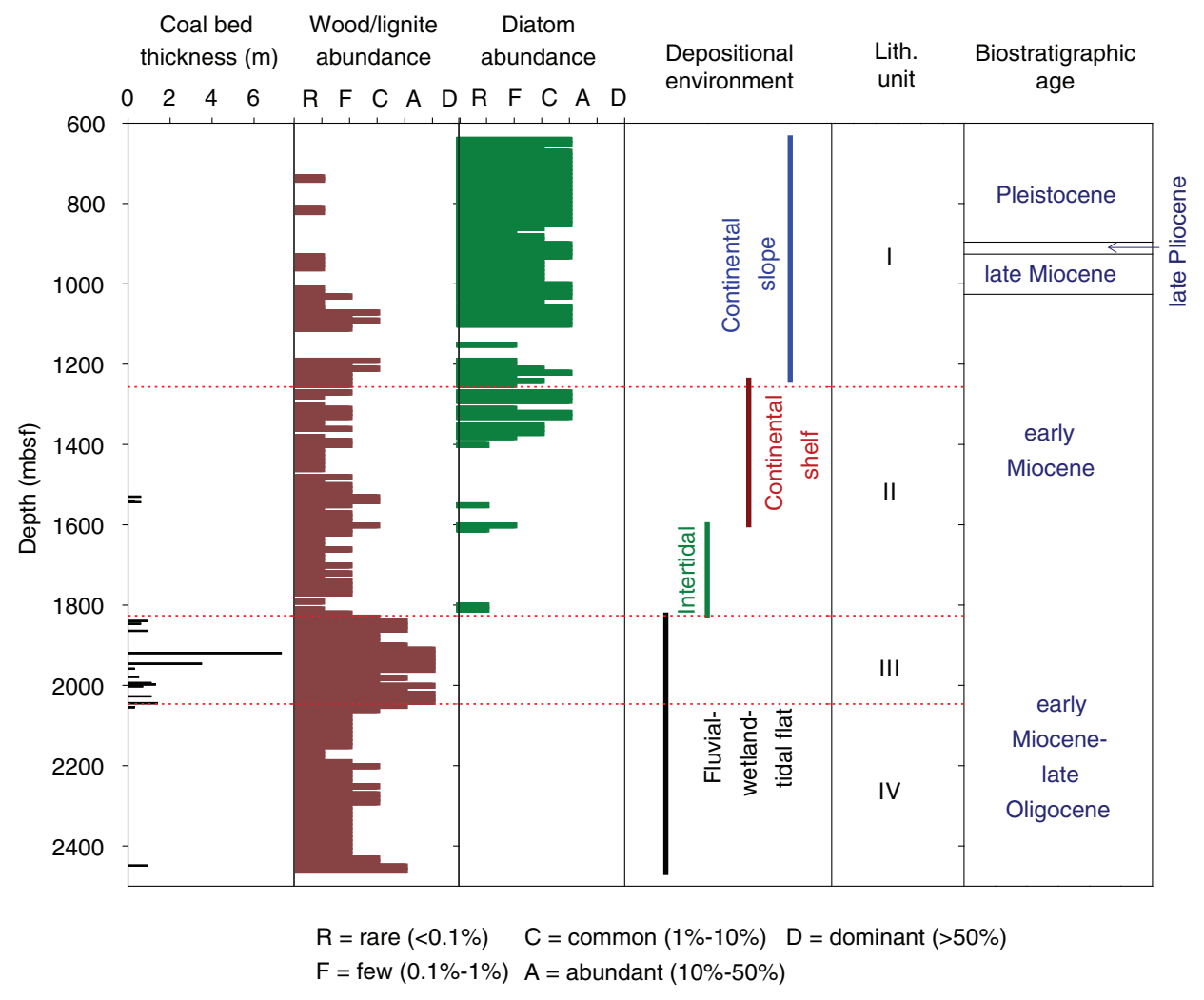


Figure F2. Core images showing the location of selected samples collected for this study. Samples were selected to avoid contamination by drilling mud. Images from Expedition 337 Scientists (2013b).
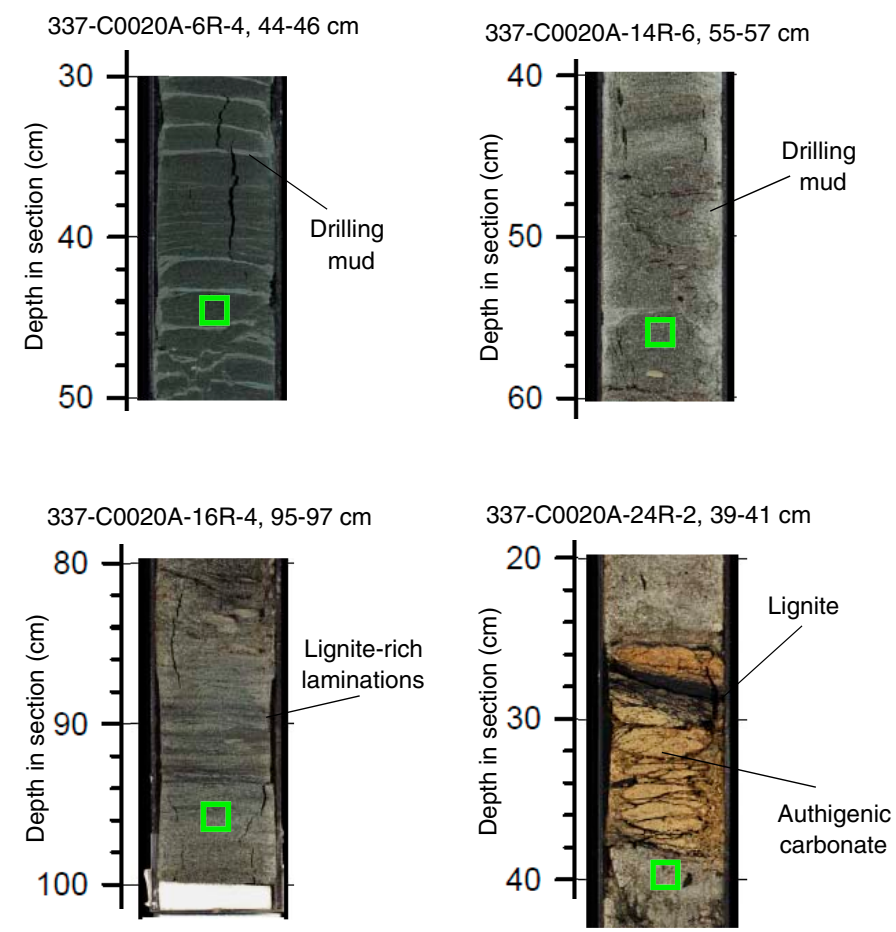

Figure F3. Particle size distribution for unconsolidated sands in Unit II.

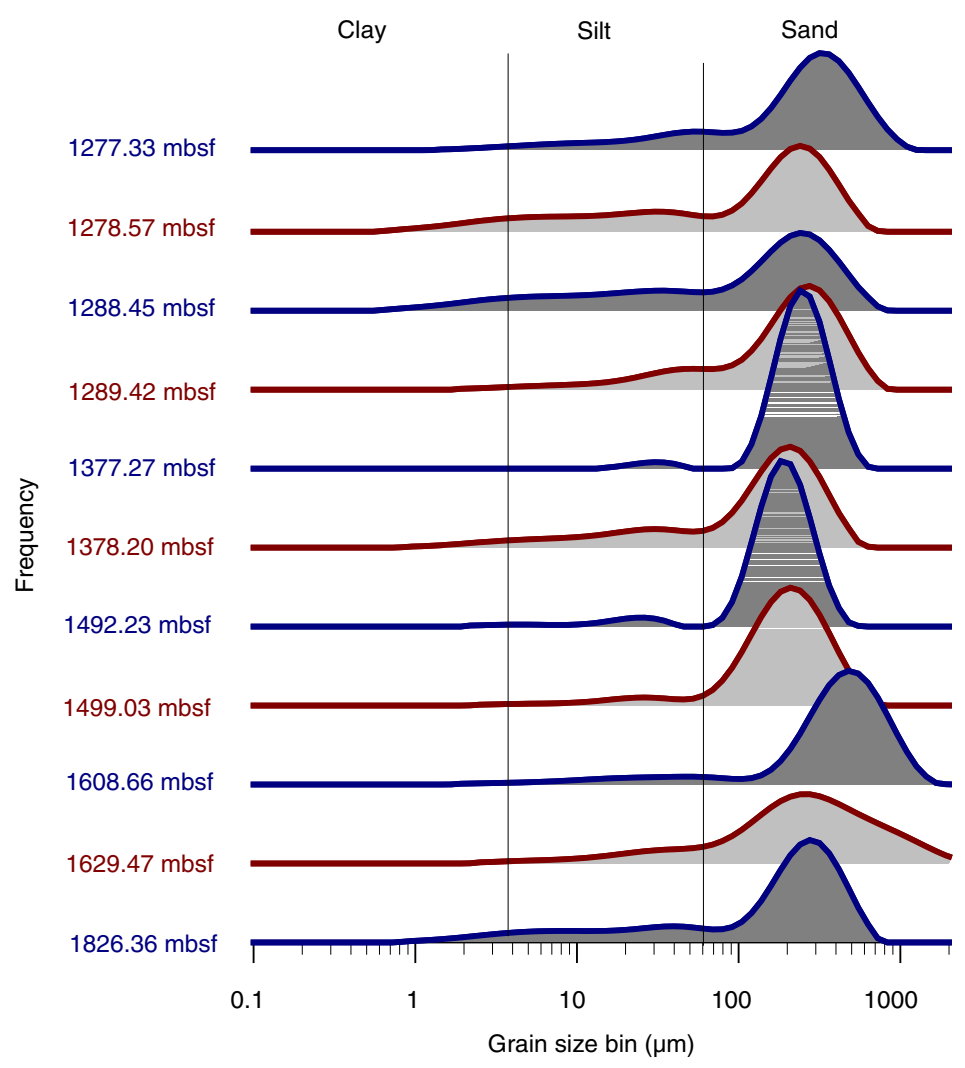


Figure F4. Particle size distribution for unconsolidated sands in Unit III.

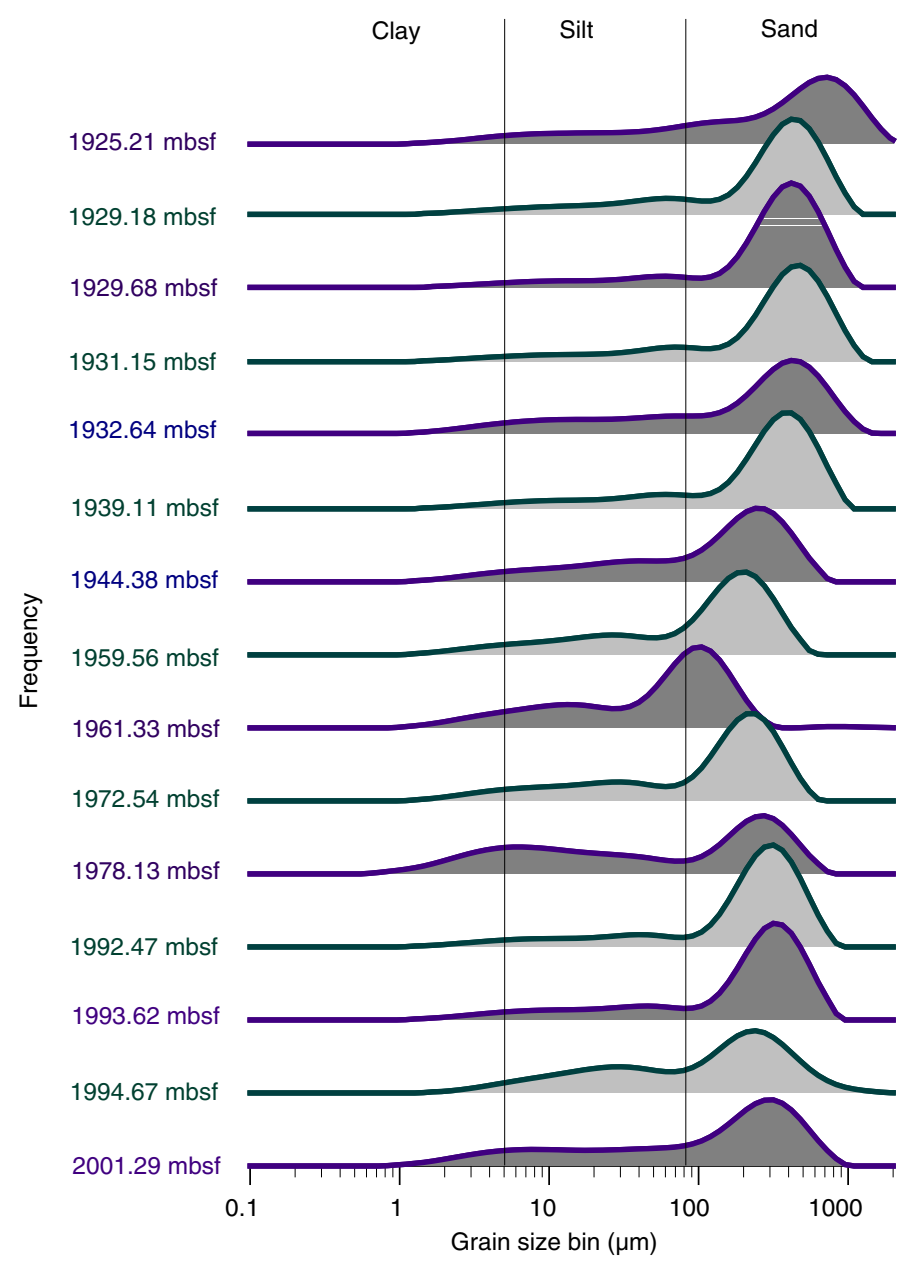

Figure F5. Sand-silt-clay percentages plotted on a ternary diagram based on the classification system of Shepard (1954).

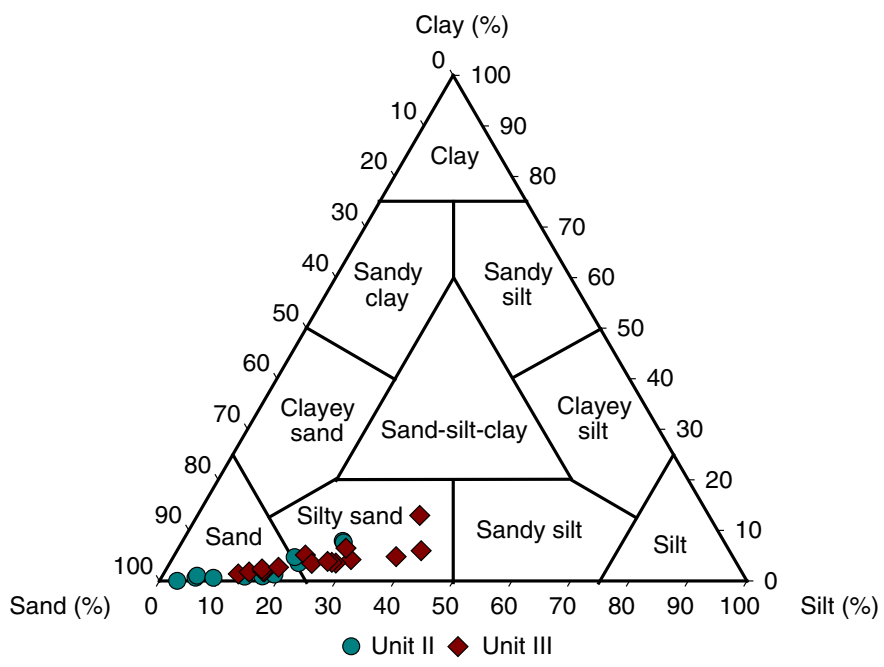


Figure F6. Downhole variation in summary statistics for unconsolidated sand samples in Hole C0020A.

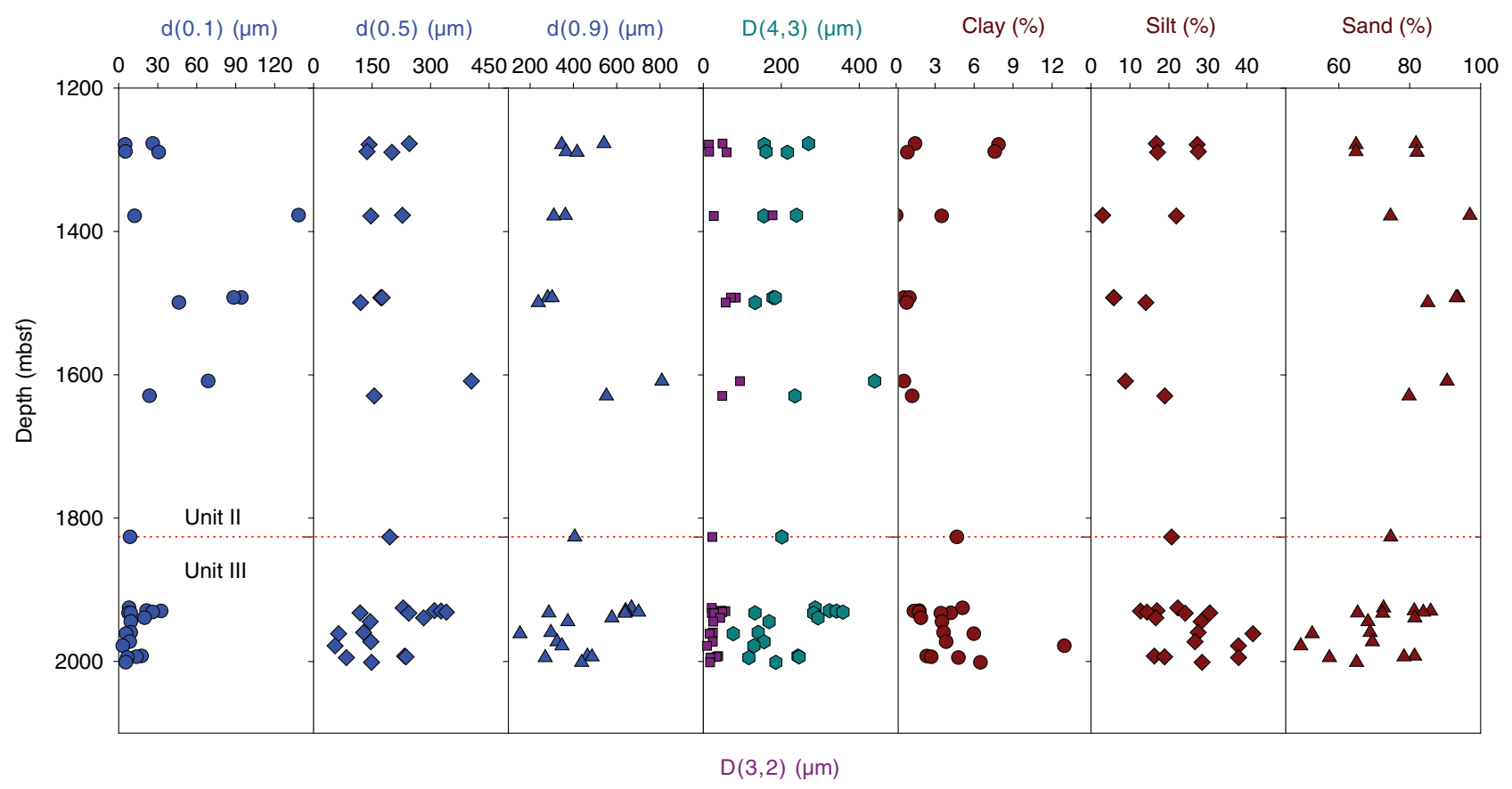

Figure F7. Downhole variation in summary statistics for unconsolidated sand samples in Unit III, Hole C0020A.

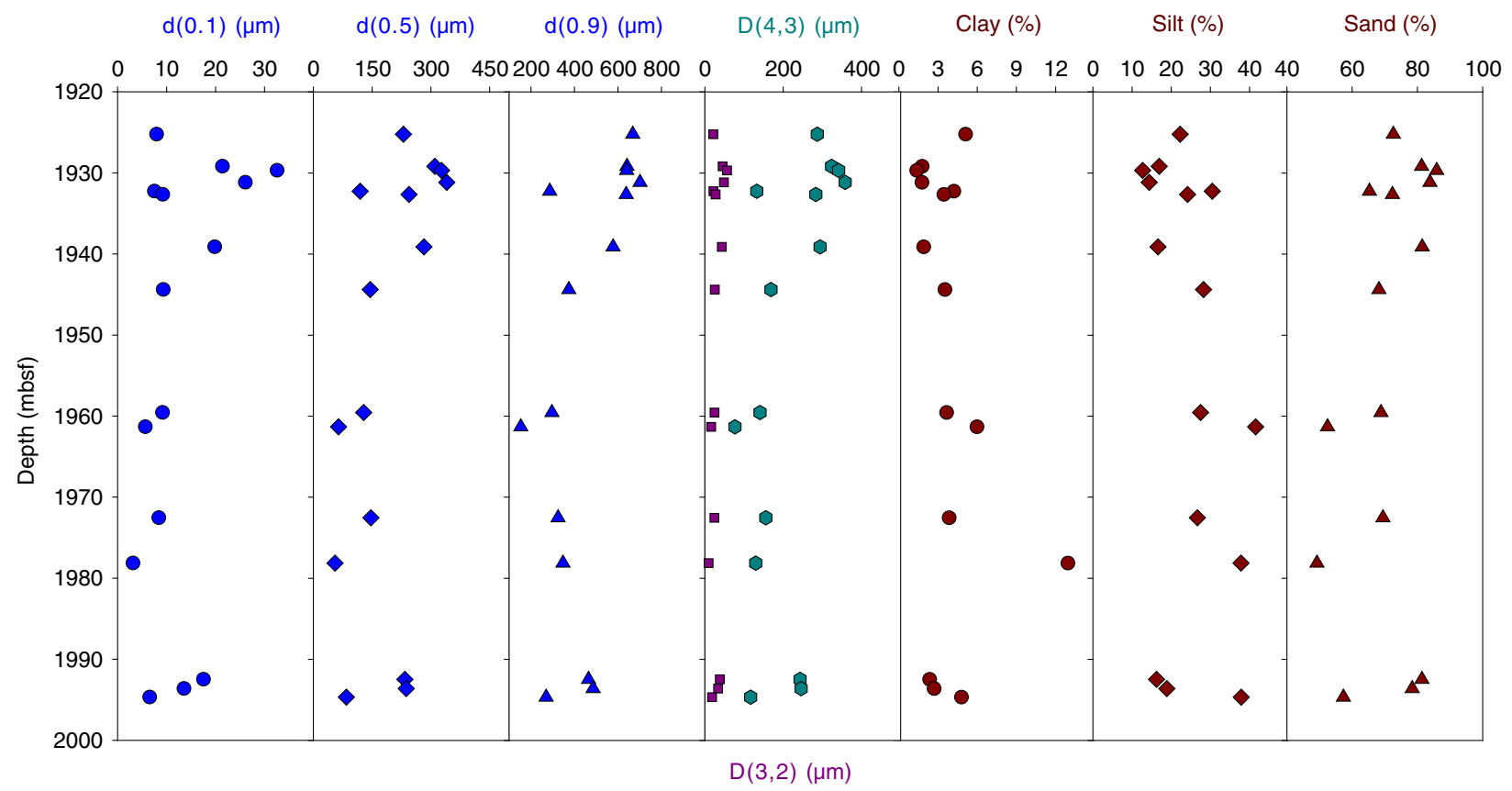


Table T1. Grain size distribution of Hole C0020A samples.

\begin{tabular}{|c|c|c|c|c|c|c|c|c|c|c|}
\hline $\begin{array}{l}\text { Core, section, } \\
\text { interval }(\mathrm{cm})\end{array}$ & $\begin{array}{l}\text { Depth } \\
\text { (mbsf) }\end{array}$ & $\begin{array}{l}\text { Lith. } \\
\text { unit }\end{array}$ & $\begin{array}{l}\mathrm{D}(4,3) \\
(\mu \mathrm{m})\end{array}$ & $\begin{array}{c}\mathrm{D}(3,2) \\
(\mu \mathrm{m})\end{array}$ & $\begin{array}{l}\mathrm{d}(0.1) \\
(\mu \mathrm{m})\end{array}$ & $\begin{array}{l}\mathrm{d}(0.5) \\
(\mu \mathrm{m})\end{array}$ & $\begin{array}{c}\mathrm{d}(0.9) \\
(\mu \mathrm{m})\end{array}$ & $\begin{array}{l}\text { Clay } \\
(\%)\end{array}$ & $\begin{array}{l}\text { Silt } \\
(\%)\end{array}$ & $\begin{array}{l}\text { Sand } \\
(\%)\end{array}$ \\
\hline \multicolumn{11}{|l|}{ 337-C0020A- } \\
\hline $1 \mathrm{R}-1,82-84$ & 1277.33 & $\|$ & 270 & 49 & 26 & 246 & 541 & 1 & 17 & 82 \\
\hline $1 \mathrm{R}-2,79-51$ & 1278.57 & ॥ & 156 & 14 & 5 & 142 & 346 & 8 & 27 & 65 \\
\hline 2R-2, 104-106 & 1288.45 & ॥ & 161 & 15 & 5 & 137 & 367 & 8 & 28 & 65 \\
\hline $2 \mathrm{R}-3,60-65$ & 1289.42 & ॥ & 216 & 60 & 31 & 201 & 417 & 1 & 17 & 82 \\
\hline $4 \mathrm{R}-2,84-87$ & 1377.27 & ॥ & 239 & 178 & 138 & 228 & 363 & 0 & 3 & 97 \\
\hline $4 \mathrm{R}-3,74.5-77$ & 1378.20 & ॥ & 155 & 27 & 12 & 147 & 309 & 4 & 22 & 75 \\
\hline $5 R-3,36.5-39$ & 1492.23 & ॥ & 179 & 83 & 94 & 172 & 282 & 1 & 6 & 94 \\
\hline $5 R-3,36.5-39$ & 1492.23 & ॥ & 185 & 71 & 88 & 176 & 302 & 1 & 6 & 93 \\
\hline $6 \mathrm{R}-4,44-46$ & 1499.03 & ॥ & 133 & 57 & 46 & 121 & 238 & 1 & 14 & 85 \\
\hline $8 \mathrm{~L}-6,49-51$ & 1608.66 & ॥ & 440 & 94 & 69 & 405 & 808 & 1 & 9 & 91 \\
\hline $9 \mathrm{R}-4,108-110$ & 1629.47 & ॥ & 235 & 48 & 24 & 156 & 552 & 1 & 19 & 80 \\
\hline $14 \mathrm{R}-6,55-57$ & 1826.36 & ॥ & 202 & 23 & 9 & 195 & 406 & 5 & 21 & 75 \\
\hline $15 R-6,115-116$ & 1925.21 & III & 287 & 21 & 8 & 230 & 668 & 5 & 22 & 73 \\
\hline $16 \mathrm{R}-1,67-68$ & 1929.18 & III & 324 & 45 & 21 & 310 & 641 & 2 & 17 & 81 \\
\hline $16 \mathrm{R}-2,15-18$ & 1929.68 & III & 342 & 56 & 33 & 327 & 640 & 1 & 13 & 86 \\
\hline $16 \mathrm{R}-3,86-88$ & 1931.15 & III & 358 & 48 & 26 & 341 & 702 & 2 & 14 & 84 \\
\hline $16 R-4,95-97$ & 1932.25 & III & 132 & 22 & 8 & 119 & 286 & 4 & 30 & 65 \\
\hline $16 R-5,32-34$ & 1932.64 & IIII & 283 & 27 & 9 & 244 & 638 & 3 & 24 & 72 \\
\hline $17 \mathrm{R}-4,40-41$ & 1939.11 & III & 294 & 43 & 20 & 282 & 578 & 2 & 17 & 81 \\
\hline $17 \mathrm{R}-9,22.4-25$ & 1944.38 & III & 169 & 25 & 9 & 145 & 374 & 4 & 28 & 68 \\
\hline $20 \mathrm{R}-1,5-7$ & 1959.56 & III & 141 & 24 & 9 & 128 & 296 & 4 & 28 & 69 \\
\hline $20 \mathrm{R}-2,41-43$ & 1961.33 & III & 77 & 16 & 6 & 64 & 153 & 6 & 42 & 52 \\
\hline $21 \mathrm{R}-\mathrm{CC}, 2-4$ & 1972.54 & IIII & 156 & 24 & 8 & 147 & 325 & 4 & 27 & 69 \\
\hline $22 \mathrm{R}-5,48-50$ & 1978.13 & III & 130 & 9 & 3 & 55 & 347 & 13 & 38 & 49 \\
\hline $24 \mathrm{R}-1,45-47$ & 1992.47 & III & 243 & 38 & 18 & 234 & 465 & 2 & 16 & 81 \\
\hline 24R-2, 39-41 & 1993.62 & III & 246 & 34 & 14 & 237 & 486 & 3 & 19 & 78 \\
\hline $24 \mathrm{R}-\mathrm{CC}, 5-7$ & 1994.67 & III & 117 & 18 & 7 & 84 & 270 & 5 & 38 & 57 \\
\hline $25 \mathrm{R}-5,129-131$ & 2001.29 & III & 186 & 17 & 5 & 149 & 438 & 6 & 28 & 65 \\
\hline
\end{tabular}

